\title{
Turismo y patrimonio desde el cerco del acontecer ${ }^{1}$
}

ISABEL RODRÍGUEZ CHUMILLAS

> Universidad Autónoma de Madrid, Madrid, España. isabel.rodriguez@uam.es

Universidad de Valparaíso

Facultad de Arquitectura

Revista Márgenes

Espacio Arte Sociedad

Turismo y patrimonio desde el cerco del acontecer

Septiembre 2015 Vol. 12 № 16

Páginas 65 a 78

ISSN elec. 0719-4463

ISSN imp. 0718-4034

Recepción: Agosto 2015

Aceptación: Noviembre 2015

\section{RESUMEN}

¿Desde cuándo lo que vemos son interpretaciones y versiones de lo viejo? Si por un lado, el legado es inequívocamente complejo porque simboliza el devenir de la imparable metamorfosis del territorio y sus gentes; y por otro lado, la intensidad de las prácticas turísticas han penetrado los entre pliegues de los lugares, reconfigurándolos con fuertes transformaciones que los habilitan para la visita. Entonces, necesariamente, la relación patrimonio y turismo condensa uno de los grandes retos de estos tiempos, pues afecta a la herencia en su más amplio sentido, la reconfiguración turística de los lugares.

El territorio retiene en formas materiales las surgencias de significados cambiantes en el tiempo, cristalizando en sus paisajes los actos y decisiones labradas por el quehacer del hombre. Una herencia única con las mismas imágenes que se dicen de formas diferentes y, por supuesto, con significados en continua transformación: el continuo resultado del arte por excelencia del saber hacer, de la acción y el conocimiento, de la imperiosa necesidad del actuar y del conocer consecuente que obliga a un eterno reinicio; a partir del paisaje y su estudio, se explicitan las expresiones de ese saber hacer, de ese arte del diseño colectivo de nuestra espacialidad. PALABRAS CLAVE

turismo, patrimonio, paisaje urbano, imaginario, arte

Tourism and heritage from the surrounding events

\section{ABSTRACT}

Since when, what we see are interpretations and versions of the old? On the one hand the legacy is complex because it symbolizes the evolution of the metamorphosis of the territory and its people. On the other hand, the intensity of tourist practices have penetrated the between folds of the places, enabling them to visit. Then the relationship heritage and tourism one of the major challenges of these times, condenses as it affects the heritage in its broadest sense, tourist places reconfiguration.

The territory retains in material forms the changing meanings over time, crystallizing in his landscapes the acts and decisions carved by the work of man. A unique heritage with the same images which are told in different ways with meanings in continuous transformation: the continuous result of art par excellence, know-how, knowledge and action. The urgent necessity of acting and the consequent meeting which obliges an eternal reboot. From the landscape and its study it is an explicit expression of that know how, that art of the collective design of our space.

KEYWORDS

tourism, heritage, urban landscape, imaginary, art 


\section{INTRODUCCIÓN}

Llevamos interesados por el turismo y sus efectos sobre los lugares y las gentes que los pueblan hace ya un tiempo. En el Blog del Seminario Internacional EntrePliegues ${ }^{2}$ se difunden algunos antecedentes y detalles recientes sobre este interés compartido y vinculado a proyectos internacionales sobre el impacto del turismo en el territorio. Realizamos acercamientos generales al turismo cultural y de interior - un turismo tan viejo como la práctica viajera pero menos concentrado y espectacular que el masivo de sol y playa-, y en especial, a los instrumentos y repercusiones de las prácticas y políticas turísticas a partir de la experiencia de campo de algunos casos concretos como la Ruta del Quijote en Castilla - La Mancha (España) y el Programa Pueblos Mágicos en México. Son acercamientos al territorio turístico en reconfiguración que se han focalizado en aspectos variados exponentes del repertorio amplio de visiones de estudio, siempre dentro de los grandes conceptos de patrimonio y turismo ${ }^{3}$ que remiten a la complejidad del legado y contribuyen al conocimiento de la condición humana.

La pregunta a examen es amplia y sigue en el aire: ¿El espacio heredado recoge la esencia del devenir en la imparable transformación del territorio y sus gentes o no? Su respuesta supone abordar en primer lugar, la complejidad del legado desde la perspectiva de los cambios provocados con la habilitación del espacio para la visita y, por tanto, del turismo como factor causal clave en la comprensión de la metamorfosis que nos acontece; y, en segundo lugar, hacerlo a través de la materialidad del paisaje urbano exponente de los estadios del acontecer.

En los casos de estudio se observa que las políticas públicas y su invención institucional de las tradiciones con fines turísticos, son determinantes en el devenir de los destinos turísticos, según se construyen o no los atractivos sobre las trayectorias de los lugares y sus gentes, o se reconfiguren sobre otros intereses y valores.

\section{DESDE EL CERCO DEL PAISAJE COMO MÉTODO Y TEORÍA}

En el cerco del aparecer ${ }^{4}$, la ciudad como la montaña o el campo, son cognoscibles siempre e inequívocamente como pliegues que forman los entre pliegues de la línea quebrada de la continua transformación. Conviene aclarar que para que se produzca un pliegue, se necesita un punto de inflexión, a la larga de ruptura. Y que esos puntos de inflexión, paradójicamente, son los que quedan visibles explícitamente, pues los demás desaparecen, son pasado/s y son futuro/s, vienen y van en direcciones contrapuestas, ya no están visibles en el cerco del aparecer de Trías (1991) en el acontecer del devenir. En esos puntos de cambio radical, provocados o espontáneos, se constituye un ámbito de transición que con mayor o menor intensidad manifiesta el cambio.

¿Qué es el entre pliegue urbano? Es posible se trate de la meseta de Méndez (2010, 2012), esos espacios ordenados y contrapuestos al intersticio, pese al carácter intersticial, netamente fronterizo, del límite imposible al que remite como lo que media entre espacios plegados o pliegues. Consciente del hermanamiento conceptual con las teorías de los pliegues, incluidas las genuinas papirofléxicas, el entre pliegue urbano pese a parecer límite es, por el contrario, meseta y en ocasiones, puente. Como dice Besse, La filosofía no es tanto una producción reglada de significaciones en el cálculo de unas razones como una resolución que se dirige al lugar del sentido, a dónde el sentido tiene lugar puntos del mundo donde cristaliza el significado de las cosas (...) el punto sensible alcanzado y obtenido es como la fractura o la brecha (las palabras son de Péguy) por la que el orden constituido de las cosas es separado, es puesto en movimiento, es propiamente reanimado. El punto sensible es el punto de ruptura y de liberación de los mecanismos y de las instituciones de todo orden (Besse, 2010:175). Entonces, ¿dónde están o cuáles espacios son intersticio urbano? ¿Es lo que está debajo de la zona de cambio, el contrapunto de lo que se ve cuando acontece y es, o es el espacio comprimido, ese ángulo más agudo de la visión frontal y vertical, cuando aún no se ha dado? 0 ¿Es el intersticio ese espacio que queda más cercano a ese ámbito entre pliegues, zona de residuo o de embrión, antes de hacerse visible, ordenarse, asumirse, codificarse?

\section{Figuraciones del límite ${ }^{5}$}

Es recurrente la idea de explicar el paisaje urbano contemporáneo asemejándolo a la lectura formal en términos de geomorfología terrestre con el lenguaje fisiográfico del territorio ${ }^{6}$. Porque se ve. Entonces, una geografía urbana estructural es la forma alegórica de asignar teoría científica para explicar los paisajes urbanos actuales. Obviamente, no se puede tratar de una traslación formal, pese a que del mismo modo se trata de dar un explicación a las formas que toma el territorio tras la acción humana y la habilitación cultural del medio en su condensación máxima que vienen siendo las agrupaciones humanas y la formación de lugares, pueblos, ciudades..., sino conceptual. No se trata de una traslación evidente entre la forma, que no obstante impone significados ineludibles y muy obvios, y lo que representa y sugiere, implica e impone a los que la utilizan y contemplan.

Mesetas, picos, valles y vaguadas, sirven para la lectura de los significados del paisaje urbano. Y al igual que el árbol impidió ver el bosque, las morfologías resultantes de la geometría de la planificación, física o económica, impiden y falsean la lectura formal de lo urbano porque contraponen e imponen al diseño histórico, colectivo y cacofónico heredado, los esquemas de cada nueva ordenación pública, cargada con significados de orden, calidad, moda, seguridad, tranquilidad, bonito, moderno. Por eso, la suma de espacios ordenados y codificados con los resultantes de la irregularidad, componen nuestros paisajes urbanos actuales.

La abstracción del estudio del territorio y su sociedad al margen del cerco $^{7}$, es decir, de la consciencia, que con la escusa de la acción en busca de operatividad anula cualquier re-significación y, por consiguiente, la posibilidad de comprensión. No podemos seguir abordando el estudio de las ciudades, por el contrario, se requiere de otros especialistas que desbloqueen la aparentemente cerrada visión de los profesionales de la ciudad. Un elenco enorme de técnicos urbanos, expertos en su economía, diseño y funcionamiento que reaplican fórmulas genéricas sin comprensión alguna de las guerras silenciosas que se batallan en ella. Desde la geografía, lectora del medio físico y social, el discurso teórico del paisaje posibilita acercamientos comprensivos al abrir dimensiones imprevisibles reconociendo la importancia de los significados para explicar la realidad, ese tiempo real del acontecer de cada sujeto devenido en sociedad y heredado en el imaginario colectivo, o, la herencia en su más amplio sentido.

Una herencia única con las mismas imágenes que se dicen de formas diferentes y, por supuesto, con significados en continua transformación: el continuo resultado del saber hacer, del arte por excelencia del saber hacer, cualquier cosa, es decir, de la acción 
y el conocimiento, de la imperiosa necesidad del actuar y del conocer consecuente que obliga a un eterno reinicio. El paisaje lo va registrando, en la ciudad actual a ritmos e intensidades feroces de la mano del hombre con la ciencia y la técnica.

Por su contribución a elementos claves de la comprensión del pasado, de un conocimiento menos mediatizado de la memoria histórica, es trascendental vincular el estudio del paisaje contemporáneo con esta vocación dialogante que posibilita como límite con las dimensiones invisibles de la realidad: mantenerse en el umbral, constantemente, recomenzar desde allí, dice Besse autor de "En los pliegues del mundo" siguiendo al filósofo Péguy que El pensamiento, según Péguy, se mantiene en el límite del mundo, en su superficie de contacto, no se instala. Todo paisaje es una zona de contacto donde se da a una velocidad infinita el cruce del mundo y el de la conciencia. De ahí, la gracia del paisaje y del pensamiento (2010:183).

Estudiamos las caras del límite, figuraciones cambiantes de la representación de las cercas, fronteras en la frontera de Trías, que van formando el rastro del devenir en sus paisajes, acumulando patrimonio y posibilitando el entendimiento general de lo visible, y cualquier paisaje urbano que preserva el valor del signo visible en su figuración (representación) y tangibilidad (física-territorial), es el puente a la sensación misteriosa y profunda de los imaginarios sociales, pues la ciudad misma como una pintura es escritura material de comunicación profunda que posibilita lo implícito connotado del imaginario (Delacroix, 2011) ${ }^{8}$. Entonces, cualquier paisaje urbano que preserva el valor del signo visible, su figuración y tangibilidad es el puente a la sensación misteriosa y profunda de los imaginarios sociales. Por eso insistimos con Montaner (2004), reinterpretando a Christine Boyer y otros ${ }^{9}$, que el borrado de la memoria que forma parte de este teatro requiere de la materialidad del espacio diseñado y sus características formales y visuales para comunicar con las estructuras profundas del mismo y sus posibilidades imaginativas.

Nos hemos especializado, tras la atrofia de tacto, el gusto y el olfato se ha impuesto el reino de lo visual, sin embargo, la imagen es fija y se recarga de significados y, el políglota paisaje, está vivo y se reconstruye socialmente. En efecto, la naturaleza visual del paisaje, permite reconstruir la historia cultural del territorio contenedora de las ideas y contextos socio-económicos, de la situación tecnológica y de las estructuras del poder. El método del paisaje ${ }^{10}$ es del pensamiento y disecciona, estudia el mobiliario fronterizo que se asienta en lo inmueble que es fijo (Trías, 1991:45) pero no se cierra la visión de lo invisible, lo impalpable, lo implícito, lo velado, lo connotativo del diseño formal de las caras del territorio, también y concretamente de la que toma como paisajes del turismo. Entonces, las maneras de decir y de explicar desde otros discursos del conocimiento verbal, imprescindibles, no son suficientes. Si escribimos sobre la ciudad diciéndolo todo de ella como un conocimiento verbal - discursivo y despreciamos o infravaloramos el conocimiento intuitivo - simbólico, somos tan explícitos tan denotativos, tan del pensamiento que se cierra la visión de lo invisible, lo impalpable, lo implícito, lo velado, lo connotativo.

Desde la morfología urbana a las múltiples expresiones del dibujo del territorio reconocemos en la materialidad visual el modo de concretar la visión del hombre y, por consiguiente, un medidor o registro posible de su quehacer. Imparables interpretaciones objetivas responden a otros tantos sistemas simbólicos, que tratan de dar a la realidad órdenes convenidos - acuerdos sociales expresados en códigos culturalmente establecidos (Rodríguez, 2010)-, reconstruyendo cada día las ciudades, cambiando el significante y también el significado. Concebida en toda su plenitud y expresión, la materialidad misma en cualquier composición que el hombre fija y redefine sobre la misma naturaleza, la mira, la atrapa, la pinta, la fotografía, la construye, la expresa visualmente: la foto, el croquis, hasta el garabato son necesarios para una comprensión mejor y mayor de la ciudad.

Creemos que con este entendimiento de los paisajes turísticos se puede llegar a incidir en la mejora de los lugares que hoy son destinos turísticos, trabajando el conjunto de sus partes, incluidas las inmensas superficies intersticiales entre zonas reconocibles y visibilizadas de la ciudad -contenedoras de los hitos, productos y servicios turísticos-, y los espacios intermedios (Castro, 2006) sobre los que hay que averiguar si desempeñan funciones de frontera al interior. Sobre todo teniendo en consideración que las políticas públicas aplican diferenciadamente sus programas, en general, polarizando sus intervenciones discrecionalmente, por lo que es pertinente no seguir prescindiendo de la visión del conjunto de la ciudad y sus partes, ahora que han alcanzado dimensiones inéditas contrastando los ámbitos más nuevos con las pequeñas y viejas partes de la ciudad que han sido intensamente rehechas. Los valores reconocidos, patrimoniales y operativos - funcionales y prácticos-, segmentan el continuo edificado, en general, y reconfiguran las ciudades obviando los inmensos bordes en crecimiento continuo, espacios urbanos que renombran el territorio y fagocitan como nueva ciudad.

\section{Patrimonio: ¿identidad de la ciudad consensuada?}

Entonces ¿cómo visibilizar la ciudad histórica? vivida, sentida e imaginada en una continuada reconfiguración de usos y prácticas, siempre con pocas huellas, además frecuentemente más implícitas en las máscaras, caricaturas y rediseños que en lo que éstos explicitan, y sobre todo, en evocaciones que arman el imaginario de lo histórico. Así sigue presente ordenando buena parte de los imaginarios sociales de cada contemporaneidad.

Cada configuración resultante es una nueva ordenación del pasado del territorio. Las formas no siempre contienen las funciones evidentes, los nombres no identifican los mismos lugares, en general, desconocemos las partes actuales de la ciudad y sus modos de nombrarse, pues en la metamorfosis permanente se renombra según la expansión urbana continua ocupa nuevo suelo y sobreponen formas, usos y nombres nuevos. Por ello, planteamos el dilema de la identidad de la ciudad consensuada, en la que sólo tienen nombre las viejas partes de la ciudad, las que han sido vividas y relatadas, las del pasado, la ciudad histórica a la que se le sigue denominando ciudad histórica porque se reconocen otras existencias posibles más allá de la forma, incluso más allá de lo visible; sigue existiendo pese a que no se la identifique por la forma que adquirió, pero sí, porque ocupa el lugar del origen, algunos trazados, nombres y monumentos, las palabras y piezas clave que siguen hilvanando el valor patrimonial por ser el origen y el pasado del presente de la ciudad reconfigurada.

Todos los lugares, pueblos y ciudades, grandes y pequeños lo tienen. Pero al tiempo, son desconocidos respecto de lo que eran, con formas, nombres, extensiones, funciones que han cambiado. Es decir, una porción significativa de la complejidad de la ciudad contemporánea viene, en efecto, del desapego funcional de la forma 
urbana en su recomposición actual. No sólo por la generalización de los sistemas de producción en serie del racionalismo capitalista -que facilitaba en sus cajas de hormigón multivalentes funciones que han acelerado la renovación permanente-, sino por la intensidad de lo urbano que se hace legible más allá de la transparencia de la forma: es un vacío formal que llena la memoria persistente que se hace visible como imagen mental de la ciudad. Una comprensión de lo urbano como un cruce - un colapso-de memorias, tiempos y espacios que tejen un tramado (...) un conjunto dialógico de redes, tejida por una tela que se soporta en el espacio históricosocial (Montaner, 2004:269). Por consiguiente, enunciamos que si en las formas se leen los discursos que las crean, y estas tienen significados distintos según y cómo las codifica y recodifica el imaginario individual y sobre todo el colectivo, siempre combinando imágenes y palabras, en especial nombres, entonces se hace ineludible comprender también los significados. Juntos explicitan las expresiones, las huellas de ese saber hacer, de ese arte del diseño colectivo de nuestra espacialidad.

A veces, aún hoy, los paisajes sobreviven a la imagen y al discurso mediatizado por los intereses del hombre que atenta, permanentemente, contra su supervivencia y también se repite en la historia de los paisajes, las representaciones de morfologías y patrones constructivos anteriores que ya no son visibles por la profunda renovación urbana. Los paisajes no cesan de modificarse -fueron y ya no son-y la imagen les sobrevive sellando el discurso concreto de un tiempo mediatizado por el interés del hombre que se impone en el imaginario.

La imagen se queda fija, se descontextualiza del propio paisaje y anida, renace y se activa en el imaginario. 0 puede, de la mano del artista que no tiene de antemano una imagen mental que luego realiza, no hay realización de lo imaginario. Lo que sí se constituye es un analogón material, una objetivización de la conciencia imaginante. El cuadro manifiesta objetos, cosas, que son irreales, que no existen en ningún lugar del mundo, ni en el cuadro mismo. Sin embargo, en la tela sí existe una manifestación de lo irreal (Salvador, 2009) ${ }^{11}$. Y esta manifestación de lo irreal produce imágenes nuevas. Precisamente, la mayoría son invisibles a los ojos de la cotidianidad de la población, porque los códigos de valoración urbana de los imaginarios sociales los invisibilizan, en gran parte, porque son arquetipos paisajísticos predominantes construidos por las acciones del marketing inmobiliario que avalan las políticas públicas. La mayor parte de los paisajes urbanos actuales no se entienden, no se ven, no se consideran, no se valoran y, sin embargo, son los nuevos paisajes en construcción. La construcción social del paisaje involucra todo el territorio pero sólo son visibles los que se ajustan a las imágenes canónicas que difunden los medios masivos y se consagran cuando anidan en el imaginario, vemos los paisajes que “deseamos" ver (Nogué, 2008:378), aquellos que coinciden con la idea de paisaje construida socialmente, pese a la cruda materialidad del paisaje que no lo salva.

Es desde esta preocupación teórica que revisamos las políticas públicas de la Ruta del Quijote en España y del Programa Pueblos Mágicos en México, políticas responsables del manejo de la producción y el deseo -mediando entre los dueños y los sueños-, pues como dice Salvador González nuestro proceder metodológico, de índole analítico hermenéutica, se funda en esencia sobre el análisis directo y la interpretación personal de los contenidos narrativos, las figuras y lugares, la estructura compositiva y los elementos formales, como también los significados conceptuales presentes (2009:279). Por eso, como ya hemos señalado insistentemente, desmenuzar el sistema territorial requiere manejar un método de análisis donde la confección de las unidades de paisaje urbano que clasifican los paisajes en transformación continua, han de identificar tanto los patrones atemporales que por eficientes a la relación hombre medio - pluritemporal- se han sostenido -aguantado el vendaval de los tiempos-, como aquéllos que reconocidos y valorados por cada colectividad local se monumentalizan.

El territorio es construido y reconstruido y las ciudades turísticas, acumulan a su condición de históricas ${ }^{12}$ la recarga formal, funcional y simbólica como destinos turísticos. En ellas se explicita la contradicción de un relato fijo y un presente con cambios vertiginosos. Casi todas las ciudades turísticas tienen perfiles bien definidos, una imagen que ofrecer, una historia bien concreta que se pone en valor y que así se publicita. Así, los paisajes responden al tiempo a trayectorias y escenarios con representaciones comunes y con gran fuerza significante, como a las formas y tipos de paisajes de la experiencia cotidiana o excepcional. Es el paisaje entonces producto de la conexión entre imagen e imaginario, lo real posible de irreal imaginado. Juntos, imbricados, morfología y percepción constituyen la base del estudio del paisaje logrado a manera de diseño urbano colectivo, siempre capturando las posibilidades en las que se concretan los intentos continuos y yuxtapuestos del quehacer del hombre, de su hacer social.

Las ciudades del turismo son, cada una, versiones de su propia invención de memorias temáticas e impostadas (Montaner, 2004) del proceso continuo de construcción de la frontera del sujeto, del territorio en lenguaje operativo o económicamente negociable, o también el del cerco del aparecer de Trías (1991). En los lugares turísticos como en cualquier lugar se abre un espacio donde el fronterizo se reconoce en el mobiliario que le inviste y reviste. $Y$ algo tiene la casa como señala Adolph Loos de vestido del habitante que la habita, o investidura característica, lo mismo que otras 'unidades mayores' de emplazamiento (Trías, 1991:46), pero en ellos el vestido es siempre el mismo y hecho a la medida, son espacios recargados de los imaginarios turísticos en los que hay que dilucidar entre las memorias temáticas y el genio del lugar. Entonces, la reconfiguración de lo urbano con formas de nuevos significados, sigue requiriendo - una vez más-, el reconocimiento de esos nuevos significados, pues se trata de seguir adelante en la conceptualización del lugar - un método y teoría del conocimiento más cerca de una filosofía de la existencia (Trías, 1991) como categoría principal de la organización territorial de la sociedad.

\section{ALGUNAS POLITICAS TURISTICAS EN MÉXICO Y ESPAÑA}

El turismo cultural y de interior se promueve con políticas públicas desde hace décadas en España. Programas recientes de financiamiento de turismo cultural en el interior del territorio español -y fórmula común de desarrollo local en múltiples países-, siguen poniendo el énfasis en la apuesta por la cultura de la tierra y lo local vertebrándolo a partir del Quijote de Cervantes, es la Ruta del Quijote. Y cabe plantear el análisis comparativo con el Programa Pueblos Mágicos mexicanos para analizar si, en ambos casos, las políticas públicas aceleran y condensan, el complejo proceso de valorización cultural. Si esta invención institucional de las tradiciones con fines turísticos, construye los atractivos sobre las trayectorias de los lugares y sus gentes o si arrasa a la herencia si es que se reconfigura sobre otros intereses y valores. 
Su estudio a partir del paisaje urbano permite evaluar la reconfiguración que el turismo está provocándole. De hecho, cualquier política de esta naturaleza, engendra una alteración de las trayectorias de los lugares, que cada vez es progresivamente más intensa. El paisaje urbano expone la aventura vivida por el lugar y sus gentes, atrapando el imaginario colectivo por su vocación dialogante con las dimensiones invisibles de la realidad, testimoniando los imaginarios sociales y turísticos $y$, con ello, un conocimiento menos mediatizado de la memoria histórica reconocida y de las que han quedado en el olvido de los proyectos e intereses actuales, pero que constituyen parte de la esencia de la identidad lugareña.

En el Pueblo Mágico mexicano o en las localidades de la Ruta del Quijote en España, lo visible del pasado son teselas, reliquias y testimonios. Por tanto, una gestión urbana prudente de las políticas públicas actuales sobre el turismo cultural -de gran transcendencia económica sobre el territorio-, independientemente, de su mayor o menor número de manifestaciones, del valor único o excepcional o, incluso de una valoración por descifrar, requiere metodologías:

- Que reconozcan e identifiquen los valores y recursos, así como las pérdidas patrimoniales experimentadas en sus trayectorias, sobre todo, alteradas por las dinámicas regionales y nacionales de la economía, pero sobre todo, según la intensidad de la reconfiguración turística que algunos han experimentado de esta específica puesta en valor.

- Que identifiquen los imaginarios sociales del lugar, a través de su expresión simbólica y, concretamente, descifrando las distintas soluciones simbólicas mediante el espacio edificado y, en general, en la forma como se ha organizado la ocupación del suelo en su proceso de construcción histórica.

- Que interpreten si lo anterior se reconoce y armoniza en los elementos emblemáticos manejados del lugar turístico y, en general, en la reconfiguración turística habilitada conforme al imaginario turístico expresado en las imágenes ofrecidas al turista.

Todos los lugares sobre los que estas políticas públicas de nueva generación han actuado, son ejemplos del proceso histórico de construcción territorial y, por tanto, sus formas materiales e inmateriales han sido -casi siempre- varias veces codificadas según claves histórico - culturales cambiantes, y ya no tantas, clasificadas y protegidas, en cualquier caso, se ha inmovilizando sólo parte de la herencia "patrimonial". Si, además, un número cada vez mayor de lugares son habilitados específicamente como destinos de turismo cultural, entonces, lo más frecuente es un desmantelamiento del pasado que sólo se rescata a la par que se re-codifica. En general, a mayor dinámica económica, más rápido es el desmantelamiento del lugar heredado sometiéndolo al azote de renovaciones y expansiones radicales y continuas, agresión del presente que refuerza dualidades y esquilma herencias en su facilitación del futuro. Sin duda, el turismo cultural centrado en promover visitas a pueblos y ciudades incardinado por políticas públicas, representa un factor fundamental de las transformaciones del lugar heredado, agudizándose el dilema que sobre la herencia reposa también, la construcción de los atractivos que lo habilitan como destino turístico.

\section{Turismo en la profunda Mancha castellana}

En el caso de la -tan traída y llevada- "Mancha del Quijote", la puesta en valor con fines turísticos de este territorio tiene varias décadas ${ }^{13} y$ ofrece situaciones muy heterogéneas, representativas de la diversidad de estadios del impacto del turismo y la habilitación del lugar al mismo, pero sobre todo, como resultado de las trayectorias histórico - regionales de carácter estructural, que determinaron que muchas llegaran en estado de ruina a tiempos más recientes. La tendencia estructural en el país, de reconcentración demográfica entorno a los núcleos mayores de población dentro de cada órbita regional, condenó a muchos de los potenciales destinos turísticos a paralizaciones y ruinas progresivas, y en el caso de Castilla - La Mancha, muy agudizado en los últimos sesenta años, por haber sido región perdedora en la apuesta del modelo económico social imperante desde mediados del siglo XX, del desarrollismo urbano - industrial centrado en los ámbitos periféricos del país y de su macrocefálica capital.

\section{La Ruta del Quijote}

El turismo urbano, tradicional, y el turismo rural de desarrollo de las economías rurales que Europa ha propiciado también en España desde finales de los ochenta del pasado siglo, constituyen dos tipos y dos etapas de los lugares turísticos del interior, aquellos que no son el referente económico y sociológico de la cultura turística dominante. Para el caso regional de las que fueron las tierras del Quijote, la comunidad autónoma de Castilla - La Mancha en España, Félix Pillet ha estudiado $(2006,2011,2012)$ y encuadrado en Castilla - La Mancha los principales iconos turístico - culturales. Señala Pillet que hasta mediados de los noventa la región contaba con una serie de destinos significativos, como son dos ciudades Patrimonio de la Humanidad, Toledo y Cuenca catalogadas en 1986 y 1996, una serie de espacios protegidos, dos Parques Nacionales, Las Tablas de Daimiel (1973) y Cabañeros (1995), y seis Parques Naturales (2012). Según este autor-que de todo ello dio buena cuenta en el pasado Seminario Internacional EntrePliegues2-, constituyen junto con los conjuntos histórico - artísticos y los Paradores de Turismo, la primera etapa del turismo de interior en esta región castellanomanchega de aplicación del Programa Ruta del Quijote 2005-2014 de estudio, y de paso, han quedado señalados los principales referentes del estudio geográfico del turismo que se ha producido en Castilla - la Mancha. Su balance y advertencias corroboradas sobre el reclamo y los peligros que se crean al aprovechar la figura del personaje de ficción (Pillet y Plaza, 2006:12 $)^{14}$. El peligro, en efecto, de manipular los valores y recursos y, según este autor, confundir los lugares cervantinos (Toledo y Esquivias), lo quijotesco o lugares citados expresamente en la obra con el resto del territorio (Pillet, 2012:355).

Desde Europa, esa Europa inmersa en una aventura inacabada (Bauman, 2006:184-185), la identidad “de la Unión" se reconstruye desde un giro hacia el desarrollo rural y, posiblemente, la primera y más generalizada acción común de revalorización del territorio, haya sido la iniciativa LEADER y el programa PRODER, ambas políticas europeas de desarrollo socioeconómico de las economías rurales aplicadas a veintinueve territorios de la región, a partir de cuatro fases con impactos medibles desde los noventa y basadas en la revitalización socio territorial a partir de modelos de plurifuncionalidad económica en el mundo rural, donde el turismo se ha articulado como eje estructural de dichos territorios. Pillet, lo denominó turismo con visión territorial porque se trató de medidas interrelacionadas (turismo rural, medio ambiente y patrimonio natural - cultural) entrecruzadas con acciones, según él "innovadoras", como la promoción de casas rurales, casas de labranza y cabañas como alojamiento, diseños de rutas turísticas, construcción de museos y ecomuseos, la rehabilitación de edificios, la potenciación de 
la cerámica popular y la gastronomía, las aulas de naturaleza y la conservación e inventario de recursos. Muchos con experiencias anteriores pero carentes de una preocupación territorial explícita que en los últimos años, dentro de la cuarta fase (2007-2013) iniciada con cierta tardanza en 2010, se está apoyando, para el conjunto de las medidas, los territorios situados en la periferia o zona serrana, por decisión de la Administración regional, llevando a cabo dichas propuestas a los Centro de Desarrollo Rural (CEDER) (Pillet, 2012:354).

En ambas grandes etapas la recurrencia, al personaje protagonista de ficción, a los personajes secundarios, a los lugares, a sus costumbres, a su gastronomía, tanto en las políticas públicas como en las iniciativas de promoción turística privadas, ha sido constante. Y por extensión, entonces, al autor, y por ello, al teatro, al Siglo de Oro, a España. Sin embargo, la gran promoción turística entorno al Quijote ${ }^{15}$ es más reciente y como consecuencia de la celebración en 2005 del IV Centenario de la publicación de la primera parte de la obra. El Gobierno de Castilla - La Mancha crea la "Ruta de Don Quijote", constituyéndose como el primer Itinerario Cultural Europeo declarado por el Consejo de Europa en torno a una figura de ficción (Cañizares, 2008:70-72) e involucrando una porción grande del territorio ${ }^{16}$

El cambio político de España y de Castilla - La Mancha de mayo de 2011 no ha cambiado la idea del Quijote como emblema (Bouzy, 1993) del proyecto turístico de este territorio, pero sí los modos y los medios que, ahora de nuevo, son manejados a discreción por el poder dentro de la deriva oligárquica dominante en toda Europa tras la etapa vivida de pluralismo limitado. El año Greco de Toledo es elocuente a este respecto de cómo la agenda urbana se ha cerrado en torno a los retos de desarrollo económico, de atracción, de competitividad y de calidad del entorno (...) a los grandes representantes, altos funcionarios, cuadros de agencias y de estructuras técnicas, representantes de los grupos sociales y profesionales portadores de recursos (Pinson, 2011:351). Es decir, el proyecto turístico regional continúa apoyándose en los medios y recursos de la literatura y la pintura y, aunque con alteración profunda de las infraestructuras y programas a él vinculados, de nuevo otro centenario -de la segunda parte del Quijote para 2015- del Quijote y el del Greco - que aún se está conmemorando-, siguen concretando y articulando las políticas turísticas de la región. Así, según Pillet:

El Plan Estratégico de Turismo (2010-14) considera a la Ruta directamente un "Icono turístico" con el que posicionar el destino turístico de Castilla - La Mancha y vincular el concepto de la Ruta de Don Quijote con una imagen de marca sólida y consistente, pese a reconocer que no ha logrado convertirse en un producto capaz de hacerse un hueco en el mercado turístico. Este Plan establece el Programa Horizonte 2015 que para consolidar la Ruta propone la edificación de teatros específicos diseñando “Escenarios Quijote" para construir espacios que sean capaces de crear vínculos tangibles entre los episodios y los lugares concretos citados o referidos en la magistral obra (2011:735).

En la actualidad, entonces, se evidencia una explicitación del papel meramente de mediador comercial del icono, o mejor dicho, la conversión en producto turístico de la recreación de un pasado de ficción donde representar la representación, a base de entenderse y especializarse las localidades como equipamiento cultural, y en concreto, el teatral. Obviamente, como dice Pillet con el fin de ayudar de forma pedagógica a entender la obra a los que la van a leer, así como dar satisfacción a los pocos que de verdad la han leído y asimilado, pues no cabe duda que estamos hablando de una magistral novela, pero también la más citada pero menos leída en nuestro país, de esta forma la convertiremos de verdad en objeto de interés turístico - cultural (2012:355).

Una propuesta que pretende que la obra, referente para el mundo entero precisamente por la capacidad imaginativa de su protagonista, quede acotada a la representación en espacios habilitados y sea suficiente la eterna representación de la obra para promocionar turísticamente Castilla - La Mancha, y sobre todo, para poder reconfigurar fuertemente sus pueblos y ciudades puesto que el atractor no es el lugar sino el emblema quijote que así dispondrá de espacios de representación específicos. Porque como dice este autor En "el Quijote" se encuentra citada toda la gastronomía o cocina más popular de esta región, a la que le acompañan los vinos blancos y tintos, así como el famoso queso manchego, motivo por el cual no es necesario mencionar ni detallar (Pillet, 2012:355), nada más, añadimos. El territorio y sus gentes están pues condenados a ser parque temático donde recrear el contexto del imaginario de Alonso Quijano.

Hasta ese cambio, y dentro de ese pluralismo limitado de una democratización de las formas de intercambio político entre los grupos elitistas portadores de recursos (Pinson, 2011:351), las políticas que se han materializado son el plan sistemático de reconocimiento y señalización de valores y recursos de itinerarios a lo largo de casi 3000 kilómetros de ruta. Es decir, se trató de una propuesta de valoración de una parte grande del territorio de la región. Una labor lenta, y quizás poco efectiva que, no obstante, se han hecho al precio de la generalización de las regulaciones consensuadas, de la eliminación del conflicto de los espacios políticos locales y de la exclusión de los actores que contravienen el consenso de las élites (Pinson, 2011:351), como hemos señalado anteriormente. Ya señalaba Oscar Guerrero que:

Los medios para lograr una toma de conciencia del patrimonio a través de los itinerarios turísticos no están del todo claros. Lo evidente es que este tipo de prácticas relaciona, directa o indirectamente, a lugares y habitantes vinculados al itinerario marcado y los distingue con respecto a otros lugares. Dentro de esta política turística no parece marcarse una preocupación por crear en la ruta mecanismos de acceso, inclusión y aprovechamiento sostenible ni para consolidar aquellos objetivos de valorización, recuperación, conservación y mejora de valores y bienes comunes que se supone son evocados por una novela icono de la literatura universal. Si con el itinerario cultural se busca impulsar un cambio de patrones, pasando de la idea proteccionista del patrimonio hacia una concepción del patrimonio como vivo, la consolidación de un proyecto cultural se hace necesaria (2013:446).

Lamentablemente, en la revisión del proyecto turístico de la región ni siquiera se le da seguimiento a esto, sino que se reconoce y potencia la idea de icono/señuelo con los “Escenarios Quijote" que, en el mejor de los casos, serán Los Teatros Regionales del Quijote y el Siglo de Oro, teatros que competirán por tener en cartelera la misma representación. Sin duda, el turismo cultural centrado en promover visitas a pueblos y ciudades incardinado por estas 
políticas públicas provocará transformaciones del lugar heredado, agudizándose el dilema sobre la herencia, porque la construcción de los atractivos que lo habilitan como destino turístico se focalizan en crear una representación del espacio como espacio turístico acotado a los espacios de representación. El lugar y sus gentes serán acompañamiento.

\section{2. ¿Dónde está el Quijote si es que ésta es su Ruta?}

Un tramo del itinerario castellanomanchego -el 8 de la Ruta del Quijote- y seis estaciones para concretar el objetivo de enfatizar la dimensión subjetiva de la construcción de los lugares para su conocimiento, a fin de evaluar la gestión de las políticas públicas aplicadas en la orientación turística del territorio y reconducir su gobierno (comprobada la dificultad de anteponerla a la aplicación de medidas de transformación).

Lo hemos desarrollado a través de diversos frentes: en primer lugar, la observación directa y crítica de la mirada geográfica y del arte ${ }^{17}$; en segundo lugar, a través de la reflexión teórica y la recopilación de materiales para abrir acercamientos de investigación con los estudiantes de Turismo y, en tercer y último lugar, reuniendo a los especialistas para comprobar sus ideas - diagnóstico y las bases de sus análisis ${ }^{18}$.

Partimos de la hipótesis de que el proceso histórico de construcción territorial queda aprehendido en formas materiales e inmateriales codificadas en clave histórico - cultural y natural - medioambiental. Estas formas materiales e inmateriales codificadas en distintas claves son clasificadas, protegidas e inmovilizadas por su herencia "patrimonial". 0 bien, las formas materiales e inmateriales habilitadas como destinos de turismo cultural ya han sido poco a poco desmanteladas de sus recursos y valores patrimoniales. Es decir, en términos generales y sintéticos, la ampliación y transformación de espacios urbanos con paisajes nuevos, la polarización física y social del territorio y la sociedad, y las pérdidas patrimoniales de profundo calado ético a la condición humana, son procesos característicos del impacto del turismo y, frecuentemente, acompañan la reconfiguración de los lugares convertidos en destino del turismo interior y cultural. Así:

- A mayor dinámica económica, más rápido es el desmantelamiento del lugar heredado, sometido al azote de masivas renovaciones del espacio existente y expansiones de nuevos ámbitos territoriales.

- A mayor dinámica económica, se refuerzan las dualidades y polarizaciones tanto sociales como espaciales, explicitándose la fractura física y social en el ámbito urbano, con segregaciones territoriales y fragmentaciones socioeconómicas.

- A mayor dinámica económica para facilitar el presente, se esquilman las herencias, se consume y derrocha el pasado en lugar de apropiárselo para enfrentar el futuro.

En la observación directa y crítica de la mirada geográfica, de la sociológica y del arte, sostenida en la reflexión teórica sobre la importancia del paisaje y los imaginarios que los explican -para el conocimiento y comprensión de los núcleos urbanos y poblaciones en reconversión a destinos turísticos-, hemos corroborado cómo sus paisajes actuales son testimonio explícito de las vicisitudes de cada lugar y sus gentes.

La Ruta del Quijote, en los ejemplos contemplados, ha contribuido a sostener valores y recursos territoriales y, por tanto, la singularidad identitaria aunque sólo sea por la explicitación -en las señales

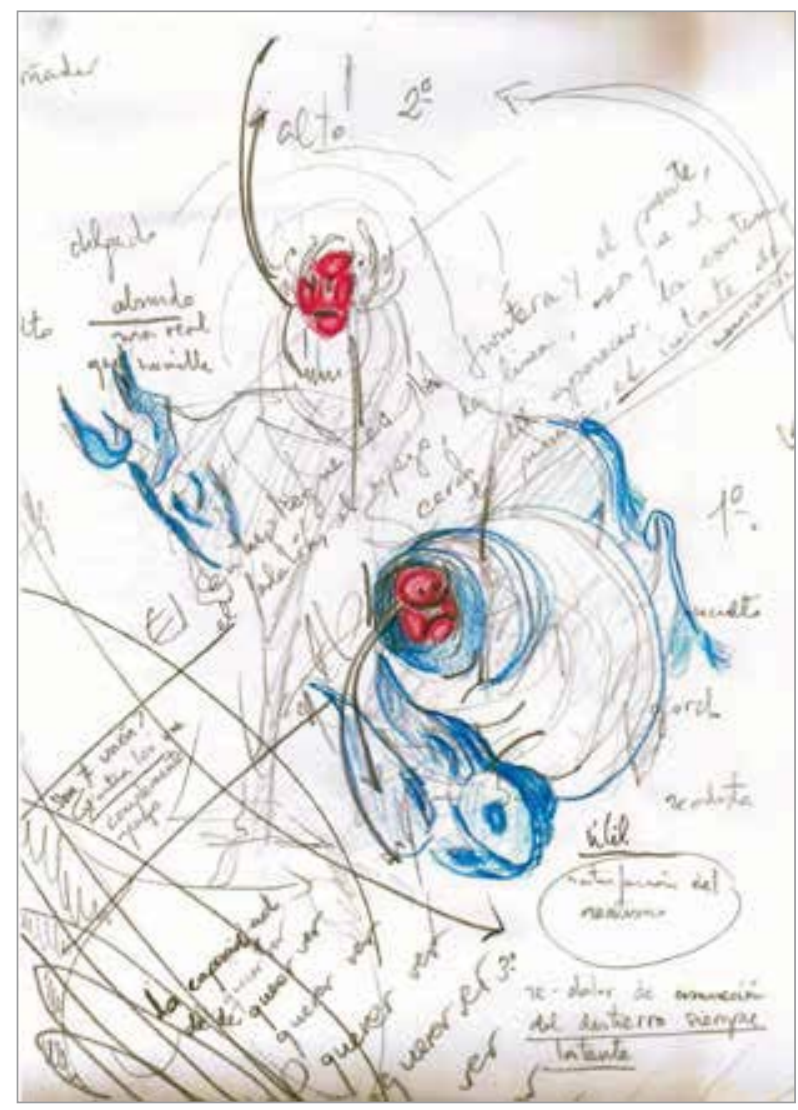

Figura 1. Quijote y Sancho, arquetipos humanos. Dibujo de I. Rodríguez, 2013. 
de la Ruta- de informaciones variadas sobre sus trayectorias, especialmente cuidadas en forma y contenido -deshabitúales en las informaciones turísticas-. Estos grandes expositores publicitados a lo largo de los múltiples caminos, carreteras y calles, además de información con gran capacidad difusora, también para los residentes supone visibilizar esos lugares, aunque para los menos, no parece sea una autorreferencia por los deficientes estados de conservación. La señalización pues, ha constituido la más sobresaliente acción de este programa, aunque resulte paradójico, sin embargo, tenemos expectativas de cambio porque el vínculo entre el territorio y su representación a través de una construcción social (...) - con- el uso de la figura de El Quijote como motivo para el conocimiento y el reconocimiento de los recursos socioterritoriales de las ciudades de Castilla - La Mancha (sigue) representan una oportunidad insólita (Guerrero, 2013:444), pese a la realidad política actual y las ideas que hasta hoy siguen aplicándose.

Dice Granalí Rodríguez, investigadora y artista plástica, evaluando la ruta en trabajos para ese fin $^{19}$ :

La existencia de una imagen, una identidad, construida a lo largo del tiempo y nutrida tanto por elementos tangibles como intangibles, es innegable a Castilla la Mancha y el Quijote. Tanto el personaje literario como el territorio castellano manchego se retroalimentan. Este valor, claramente percibido, supone una ventaja competitiva como marca turística pues el icono, la imagen publicitaria del Quijote, goza de una difusión a lo largo de la historia y las territorialidades que hacen de este personaje carta de presentación no sólo de Castilla la Mancha sino también de la marca España a nivel internacional. El Quijote ha sido fuente de inspiración para las artes plásticas, la literatura o el cine, desde hace centurias y también respecto al tema que nos ocupa: el turismo.

Con el objetivo de difundir un atractivo destino turístico que sirva de promotor de los territorios castellano manchegos, e ineludiblemente de repercusión en las arcas nacionales, se potencia y construye “la Ruta de Don Quijote”. El corredor ecoturístico más largo de Europa según reza en su publicidad, distribuido en diez tramos que recorren Castilla y La Mancha.

En el año 2005 tuvo lugar el gran despliegue para aprovechar el tirón del Centenario, con una fuerte inversión, empezando por el amueblamiento de los itinerarios y su señalización entre otros...

Los itinerarios, no mantienen una relación concreta o estricta con los capítulos o derivas de la novela sino que están forzados para dar paso o paseo obligado por esos lugares, localidades, más desfavorecidos del territorio manchego (lo que no significa que no estén llenos de atractivos que ofrecer).

Al tratarse de un territorio tan extenso es inevitable seleccionar tramos en los que realizar inmersión de estudio y así nos hemos adentrado en nuestros particulares y en otras ocasiones consensuados itinerarios de La Ruta.

Así hemos podido constatar, en los caminos visitados, como esa fuerte inversión del año 2005 se encuentra en la mayoría de los casos abandonada, desatendida y víctima del deterioro.

Fuera de las poblaciones que ya gozaban de difusión y solera en su identificación quijotesca, no se ha conseguido sumar a otras pues no es suficiente gastar grandes presupuestos en hitos y folletos (y en este caso ha quedado muy claro). Es imprescindible una labor de base, con los habitantes de los lugares y el establecimiento de compromisos políticos que trasciendan del mero balance económico o el interés populista electoral.

Esta observación presidió cada una de nuestras salidas de campo y con la misma claridad, a cada paso, se producía el descubrimiento de valores explícitos o latentes de las potencialidades que La Ruta tiene.

Llanuras extensas, campos de secano que conviven con olivos, viñas y almendros....Sierras, formaciones montañosas de pinares y encinas....Liebres y conejos de llanura que conviven con corzos y jabalís de altura.... Una paleta amplia que colorea los fogones con variadas y deliciosas viandas, concediendo al territorio de la gastronomía un interesante baluarte.

Todo el aparato desplegado en el 2005 tiene ahora una ocasión única para ser retomado: el Centenario de la segunda parte de la novela en 2015 y la muerte del escritor Miguel de Cervantes en 2016 pueden ser el gran detonante para de una vez por todas dar la proyección que merece esta "Ruta".

La ambientación de los escenarios de la novela están a cada paso, no hay que imaginarlos, solo andarlos... (Rodríguez, 2014) ${ }^{20}$.

Dice Oscar Guerrero, sociólogo, como resultado de sus primeras reflexiones tras investigar el tramo 8 y algunos de sus itinerarios:

Al utilizar Cervantes como oficio de su personaje protagónico el de caballero andante, se advierte que la geografía de la obra tiene necesariamente un carácter itinerante. Es entonces la obra un escenario propicio para invitar al turista, pues el hidalgo se escapa, tanto personal como espacialmente, y busca la aventura. El turista en ese sentido coincide con el personaje, ya que es condición de un turista estar fuera de su lugar habitual, buscando una aventura, quizá no caballeresca, pero sin duda pretende una experiencia en la que las relaciones para con el lugar de destino y sus habitantes que le provoque emociones distintas a las habituales. No es por tanto el espacio mismo la clave turística, sino la experiencia y las relaciones posibles (2013:443) (...) La oportunidad que ofrece equiparar al personaje del Quijote con el viajero turista es enorme, sin embargo requiere de un proceso de gestión que se ha dejado de lado (Guerrero, 2013:444).

La reflexión teórica y la investigación del turismo para abrir acercamientos de investigación con los propios estudiantes de Turismo ${ }^{21}$, a base de introducirles en el acercamiento al lugar, se ha realizado con el trabajo de campo para evaluar la planificación y gestión del turismo y comprobar cómo se concreta y materializa su aplicación. Los estudiantes de Turismo, tras la recopilación de materiales y análisis de los documentos políticos -que expresan el proyecto de territorio, de sociedad deseable y las propuestas de promoción turísticas previstas-, han cotejado en trabajo de campo para registrar las observaciones en diferentes formatos y lenguajes.

En términos generales, los estudiantes de turismo han asimilado las múltiples dimensiones que intervienen en la conformación de un destino turístico, sin embargo, sus recursos comprensivos y técnicos quedan reducidos a los instrumentos y fórmulas probadas del turismo como negocio y fuente de empleo, es decir, al manejo del turismo como sector económico. En su revisión sobre la influencia 
de las políticas públicas en la actualidad de los destinos, buscan principalmente caracterizar a la actividad turística, repiten sin comprobar en campo, las características publicitadas por los medios masivos y especializados sobre la localidad y su patrimonio local, sin ningún cotejo con otras fuentes y documentos sobre el destino, y eso, pese a que consiguen aislar concisamente las características y los valores de los elementos que le atribuyen las políticas públicas, en buena medida, por manejar el mismo lenguaje y perseguir los mismos objetivos, básicamente, medidos en términos económicos. Por todo ello, en general, asumen y repiten sin cuestionar ni constatar en campo, las políticas de promoción turística aplicadas u otras políticas públicas influyentes en el destino. Apenas logran identificar a los actores sociales importantes, sus relaciones y sus prácticas sociales relevantes en el ámbito turístico, más que la identificación de los directamente implicados en la actividad, bien como oferentes de servicios y actividades, bien como consumidores, esto es, la población local vinculada a la actividad turística y los propios turistas. Aunque a través del trabajo de campo y la inmersión en el lugar, se acercan a la descripción e interpretación de los elementos emblemáticos y cuestionan la escasa conexión entre las políticas públicas y los receptores en destino, pese a la constatación de la gran importancia de estas en el destino del destino turístico. Ya es un avance y ahí seguimos trabajando.

Por último, el acercamiento a los especialistas y con ellos, para comprobar sus ideas - diagnóstico y las bases de sus análisis ${ }^{22}-$ donde prima relatar y cuantificar los elementos del cambio como destino turístico-, apenas se mide el significado del cambio en términos diferentes al económico y sus distintas manifestaciones socioeconómicas.

\section{¿Dónde está la Magia en los Pueblos Mágicos?}

Sospecho que en ningún lado, pero será bueno conocer cómo los estudiosos lo han descubierto y las razones en las que fundamentan dónde han encontrado la magia y si estas políticas públicas son, verdaderamente, detectores de la magia de los pueblos que refortalecen, o si la magia es la que sostiene esas políticas, pocas veces verdaderamente mágicas.

Un acercamiento a tres pueblos mágicos, Álamos, Huasca y Huamantla, me ha permitido probar dos recursos analíticos reconocidos en la Geografía, y en las Ciencias sociales y humanas en general, a saber: 1. el trabajo de campo que para los tres casos se ha realizado con los equipos de dos proyectos de investigación públicos sobre el Programa de Pueblos Mágicos, en los que colaboro. Y 2. la comprensión geográfica del territorio, en este caso, a través de unos bocetos sobre la configuración física del territorio interpretada a través de la expresión gráfica y pictórica, sólo para el caso de Álamos (Rodríguez, 2013).

No vi magia por ningún lado, sólo la belleza y peculiaridades de pueblos y ciudades representativas de la tipología urbana mexicana, atravesados por el común denominador de las transformaciones recientes provocadas por su -mayor o menor- especialización turística. La clara distinción en ellos de los espacios de valoración turística respecto de las restantes partes del lugar, con la simplificación y codificación mercantil de sus valores patrimoniales, han provocado el reforzamiento de la polarización física y social de los núcleos a cambio del crecimiento económico vinculado a la renovación edificatoria y la producción de suelo urbano para espacios y servicios de la actividad económica. No obstante, aunque ya vi Álamos apenas conozco más.
Es un destino turístico consagrado, con productos específicos y servicios en consonancia sostenidos en su potente pasado, que aún hoy es suficiente para que en su materialidad conservada, se constate la disfuncionalidad entre los contenedores y el contenido, teatralizando sus centros originarios con el vaciado de residentes y usos ajenos a la actividad económica vinculada al turismo. En Álamos vi cuadros de pintores locales que la pintaban con Iluvia, los bordes urbanos, ruinas, elementos característicos en puertas y poyetes, tiendas, la magnificencia de portales y las columnas y los dos emblemáticos espacios públicos de la Plaza y la Alameda, una de representación y descanso y otra de comercio y diversión con sus estructuras físicas y formales acordes a esas funciones complementarias y conteniendo los elementos patrimoniales más originarios como la Iglesia y su torre del reloj.

El conjunto fija el valor turístico y local en esta parte céntrica y central de la fundación de Álamos con el callejón del Beso como puente entre ambas. Fachadas engrandecidas por la presencia de espacios de jardín o zócalos intermedios, espacios puramente fronterizos entre la calle y la casa y de presentación pública de esta última, y con un sinfín de rasantes hacia la calle por la singularidad de escalones y zócalos a distinta altura y profundidad. Las dificultades con el arco de medio punto en las arquitecturas más antiguas, la desarticulación entre los portales sin paso entre vecinos, los escalones para evitar la frecuencia de las inundaciones históricas de climas cuyos regímenes de precipitaciones son tan contrastados, con amplias sequías y períodos de lluvias reforzados por las morfologías montañosas de su entorno natural que, sin embargo, no han impedido un callejero con trazados topofílicos que traducen su naturaleza y logran perspectivas idílicas y que ya observamos desde la representación cartográfica digital y capturamos en los bocetos morfogenéticas de la configuración del núcleo. Las avenidas principales son ríos libres desde las montañas, ríos y ramblas con socavones atravesados por puentes y dobles puentes que contornean todo el núcleo viejo como si de las puertas de la muralla se trataran.

Sin embargo, Huasca aun respondiendo a una pequeña localidad con un potente pasado asimismo como la anterior, su distribución anula cualquier intento de teatralización del patrimonio local que el propio núcleo constituye, puesto que el más valioso se encuentra fuera del núcleo urbano ya que los restantes testigos de la memoria han sido casi destruidos y profundamente remodelados. Algunos de sus elementos fundacionales no obstante, callejero principal, iglesia, plaza y portales, desempeñan también la función de atractores turísticos concentrando la actividad comercial de los alrededores. Los recursos y servicios turísticos más importantes son las Minas vinculadas al agua de un singularísimo afloramiento rocoso, temprana y agresivamente impactado por la visita. Sólo el río se ha incorporado a la visita bajo el ingenio performático de la representación de los mitos y los ritos locales rescatados en forma de leyenda reinterpretada por los jóvenes emprendedores.

La ciudad de Huamantla capea el futuro con devoción por sus tradiciones artesanales y taurinas, carente de distrito turístico propiamente o muy exiguo circunscrito a unas pocas calles pues el resto han transformado mayoritariamente sus fisonomías y funciones antes del Programa PM. El tapete -como el encaje de Almagro $^{23}$ - está asentado en la tradición local y se activa y renueva como producto turístico, los toros en Huamantla como el teatro de Almagro son prácticas de ocio y cultura, arraigados y fomentados turísticamente y que singularizan la oferta de atractivos visitables. 


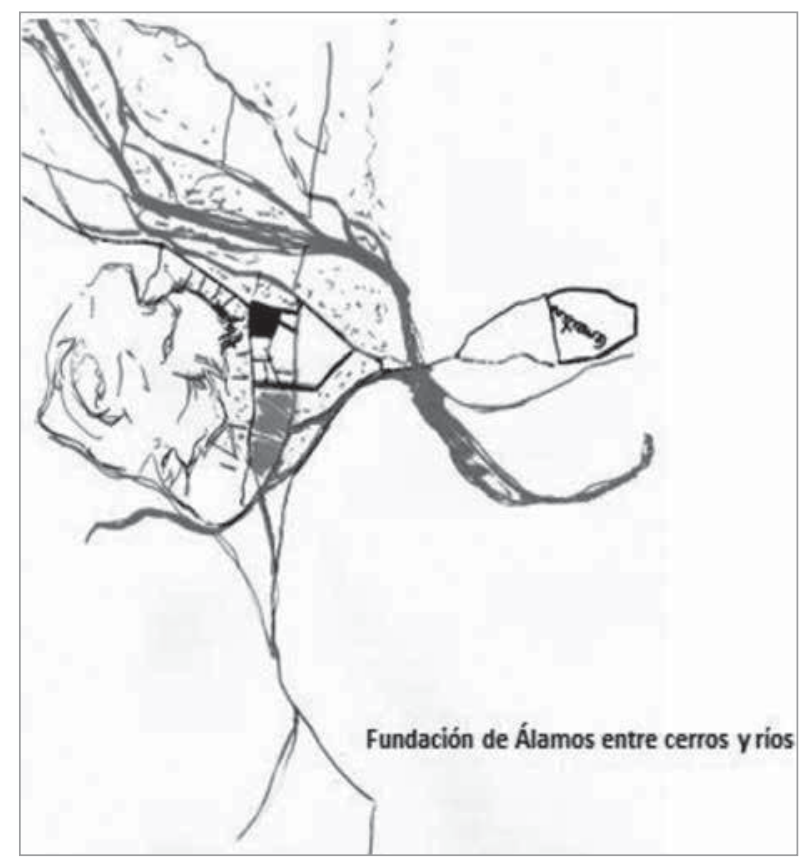

Figura 2. Croquis con la forma de ocupación territorial de Álamos a partir de la imagen de Google Earth. Dibujo de I. Rodríguez, 2012.
Es, precisamente, una figura como el Quijote de Huamantla el que nos sirve para identificar una apuesta turística a partir del reforzamiento de temas y equipamientos culturales de más calado, con la creación del Museo de la Marioneta. Pareciera que en Huamantla ser PM tampoco ha alterado su orientación de destino turístico sustentado en el patrimonio inmaterial de las prácticas religiosas y culturales históricamente construidas en la trayectoria de la ciudad.

La magia no hace milagros pero ser Pueblo Mágico ayuda a alcanzarlos y los estudios sobre tipos y números de empleos vinculados al crecimiento del sector turístico, así como las mejoras urbanas en servicios e infraestructuras, son concluyentes respecto al interés local por la activación económica de sus lugares a partir del Programa Pueblos Mágicos.

\section{ENTRE PLIEGUES DEL TURISMO EN LA RUTA DEL QUIJOTE Y LOS PUEBLOS MÁGICOS}

¿Dónde está el Quijote? ¿Dónde está la Magia? Precisamente, en un Pueblo Mágico mexicano, Don Quijote ocupa su lugar. No es un lugar de la Mancha, pero es mágico y también tiene su Quijote. Dice Wolfgang Matzat, en su libro "La Modernidad de Cervantes" (2013) donde analiza la construcción y representación de los mundos sociales de su obra novelesca, que el vínculo entre la literatura impresa y la formación de un imaginario colectivo, en el caso del Quijote, tiene una orientación nacional muy clara, sin embargo, está también en el Museo de marionetas de Huamantla sin dejar de ser para España y Castilla - La Mancha el icono por excelencia de su autorreferencia.

Por eso nos interesa conocer qué estructura espacio temporal del mundo ficticio hay en el Quijote, cuya estrategia textual se inicia situando su origen en la Mancha, el pueblo Toboso, los campos de Montiel, el puerto Lápice, las lagunas de Ruidera y la sierra ${ }^{24}$ Morena, es decir, provocando una españolización de las correrías que transforma profundamente el cronotopo del camino:

El camino no lleva por mundos extranjeros, sino por la patria, de modo que se manifiesta la variedad socio - histórica del país natal, citando a Bajtín (1989:251-396). Éstos, además de facilitar las aventuras, están marcados por las funciones prácticas que tiene las carreteras en la España del Siglo de Oro (141) sirven para conectar las distintas partes de España (...) los personajes provienen de diferentes regiones (...) presupone unos conocimientos geográficos y culturales de los que solo dispone un lector familiarizado con la Península Ibérica o, dicho de un modo mucho más rotundo, un lector español. (...) lugares conocidos (Matzat, 2013:141). El análisis que desvela el hispanista alemán sobre los cronotopos literarios, concluye sobre su carácter nacional situando la acción en un territorio limitado, anclado en una realidad geográfica sumida en una organización política de estado, un idioma, unas costumbres comunes: Por su manera de presentar el mundo ficticio, por los conocimientos lingüísticos, geográficos e históricos que presupone, fija las características de esta comunidad y, con ello, su extensión y sus límites (Matzat, 2013:140). Es un viaje el de Don Quijote que contribuye al nacimiento de una conciencia nacional, que como dice Matzat facilitaron la percepción del territorio recorrido como una unidad política (siguiendo a Anderson 2006:53-56, 2013:141) $)^{25}$.

Sin embargo, el Quijote es al tiempo, atemporal y se desterritorializa. Una explicación interesante la da el mismo romanista indicando que esta obra, vista en el contexto de toda su producción investiga- 
dora sobre Cervantes, introdujo alteraciones respecto al cronotopo del camino porque se pone a prueba, no el valor heroico de Don Quijote como en las novelas de caballerías, sino su ingenio, su capacidad de transformar la realidad por la fuerza de su imaginación (Matzat, 2013:142) y, además, recalca el nuevo tipo de aventuras que propone, y que va a posibilitar descubrir la realidad española contemporánea escondida tras la visión desfigurada de don Quijote (Matzat, 2013:142). Entonces, No lleva a regiones alejadas de la realidad sino que permite una visión imaginaria de la propia realidad (Matzat, 2013:142), además de dar cuenta detallada de esa España, que se recrea y reversiona en los escenarios del turismo interior o castellano - manchegos, del conjunto del país e incluso del mundo entero, porque funciona como mediador de ese otro lado, es entonces el Quijote, el Puente de la visión delacroixiano.

Transformar la realidad por la imaginación y crear visiones imaginarias de la realidad, son las razones del éxito y del mito y por eso andamos de andanzas con el imaginario para comprender la configuración actual de los lugares. Delacroix expresó -ya lo decíamosqué es el imaginario social y como llegar a través de un puente misterioso que se establece entre las almas, entre lo que se ve, la naturaleza exterior, que sin embargo se piensa interiormente, el verdadero pensamiento que es común a todos los hombres (...) y que desaparece al accederse al sentido (Delacroix, 2011:3).

Hay lugares que han atinado, o mejor, hay lugares que han desatinado menos... Por eso identificar valores y recursos y registrar las pérdidas patrimoniales de estas políticas públicas, incentivando o deteniendo la progresiva -y frecuentemente dramática- alteración de las trayectorias de los lugares en reconversión turística, sobre todo, porque el hombre no va a parar de moverse, es más, por eso ni los medios ni los modos de hacerlo parecen que vayan a detenerse. Quizás porque dependen de eso, de la condición humana. Y como decía Cernuda: cuando se aprende que ni la vida ni el mundo eran, o al menos no eran sólo, aquel rincón nativo (Cernuda, 2002:344) (las paredes que velan sobre su existir), la realidad se achica y agranda la imaginación, ha nacido un deseo que consiste en un afán de ver mundo, de mirar cuanto se nos antoja necesario, o simplemente placentero, para formación o satisfacción de nuestro espíritu (Cernuda, 2002:345). Y cualquier señal provoca a la imaginación siempre dispuesta al periplo: Mas nunca sabremos que no mudaríamos de corazón, de no correr allende los mares. Lo cual de por sí sería ya razón suficiente para ir de un lugar a otro, manteniendo al menos así, viva y despierta hasta bien tarde, la curiosidad, la juventud del alma (Cernuda, 2002:345).

\section{CONCLUSIONES}

Dice Eugenio Trías filósofo catalán, en El artista y la ciudad que el arte forma una unidad sintética con la sociedad, con la ciudad, que sin embargo en la modernidad se desmorona, originando un arte "ensimismado" y una sociedad gobernada por principios anestéticos (1997:51, nota 35), porque el mundo objetivo, falto de contacto con el mundo subjetivo - erótico y estético- se rige por el absurdo principio de la nuda productividad y no es casual que esa productividad espoleada por el principio cuantitativo de la constante autosuperación (de manera que el objeto que persigue la producción es siempre más producción) parece tener cierto "limite de crecimiento" más allá del cual se vuelve contra ella misma. La superproducción debe entonces ser absorbida por las fuerzas de la destrucción (bien directamente, a través de la industria de la guerra, bien indirectamente a través de la industria del consu-

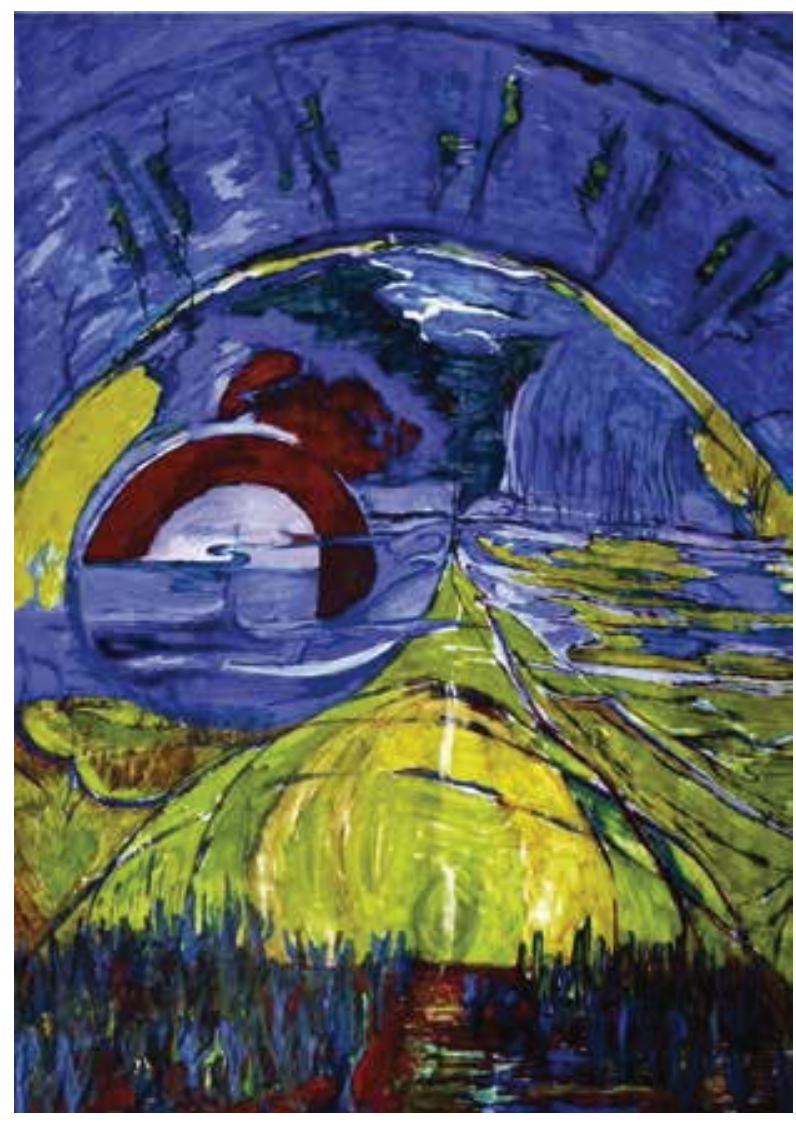

Figura 3. Hombres - zaguaros ante el cerco del aparecer. Dibujo de I. Rodríguez, 2015. 
mo planteada en términos de "obsolescencia planificada" (Trías, 1997:49). Un mundo escindido, una sociedad escindida una doble esfera separada: esfera privada del amor, esfera pública de la producción; ámbito "espiritual" del arte, ámbito "material” de la sociedad civil -económica, laboriosa-; área subjetiva del deseo, área objetiva de la praxis productiva (Trías, 1997:49).

El turismo, es precisamente, la práctica, el espacio y el negocio de la recreación máxima de esa doble escisión, con escenarios donde representarlos y experimentarlos. Las políticas públicas a examen refuerzan un mundo escindido que teatraliza esa escisión y conviene, por tanto, descubrir la realidad contemporánea que está escondida tras la visión desfigurada de dimensiones y expositores diferentes a los indicadores al uso de naturaleza y finalidad netamente mercantil.

Los paisajes urbanos actuales son la materialidad de la obra colectiva original, añadida, usada y si se valora, se le reconoce y puede al renombrar, etiquetar y señalar, quedar invisibilizada. Así, la visita al museo, la visita al centro de la ciudad, etc. como itinerarios - del camino que siguió cada lugar en su evolución- escritos en el discurso que recarga el propio lugar de memoria, desconoce y obvia, lo expuesto en sus paisajes como un mecano de restos y recomposiciones incomprensible, como un pequeño fragmento de cerámica, roto e ininteligible, casi invisible, al menos insignificante. Hay que imaginar como era toda la pieza, desde la tierra que le da forma, al agua que permite su argamasa o las manos que la crean.

Probablemente, sea un viaje imposible, primero, por intentar comprender la dimensión filosófica del cerco del aparecer - del acontecer del yo dentro del cerco fronterizo que preserva la dimensión secreta y sagrada del ser- que decía Eugenio Trías (1991); segundo, por pretender restaurar esa síntesis -que el mismo autor señalaba (1997) y apuntamos al inicio de las conclusiones- a partir, precisamente, del arte como una unidad sintética con la sociedad. Y tercero, es un viaje imposible porque remite a lo escondido tras la visión desfigurada que decía el hispanista W. Matzat (2013) sobre El Quijote y Alonso Quijano.

Pese a los riesgos, lo que acontece sobre la tierra -en la consciencia de la existencia- es ese horizonte expuesto, mostrándose en ambiente real como desierto -arrasado principio y final- con zaguaros que le significan.

Ahí te expones y quemas al sol que atrapa, a la tierra roja, las siluetas de hombres - zaguaro. Fijos ante el cerco del aparecer, abrumados, cegados por su luz, aullando por el miedo, acotados y concentrados en el cerco fronterizo, multitud de idénticos, admirados y absortos por el circo de los deseos, apegados y expectantes están sin reconocer sus ambientes. Porque el circo media con el cerco, es el límite de sus figuraciones. Un circo opaco, dónde la carpa enmarca, re-marca, en-cuadra, delimita, singulariza, individualiza, pero sobre todo separa de la realidad, como en toda comunidad cerrada. En absoluto se confunde con ella, no es la realidad, pero es real que te permite viajar porque el circo se va, muda, es itinerante por el mundo.

La idea central, en definitiva, es la del paisaje como patrimonio activo de la memoria.

\section{BIBLIOGRAFÍA}

BAUMAN, Z. (2006), “Europa. Una aventura inacabada”, Madrid: Editorial Losada.

BESSE, J. M. (2010), "La sombra de las cosas. Sobre paisaje y geografía”, Madrid: Biblioteca Nueva.

BOUZY, CH. (1993), El emblema: un nuevo lugar ético, Criticon, $\mathrm{N}^{\circ}$ 59, pp. 35-45.

CAÑIZARES, M. C. (2008), La Ruta de Don Quijote en Castilla La Mancha (España): Nuevo Itinerario Cultural Europeo, Nimbus N²1-22, pp. 55-75.

CASTRO, L. (2006), Flujos espaciales y hechizos digitales: (des) territorios del hombre. En Herrera, D. Piazzini, S. \& Carlo, E. (eds.), "(Des)territorialidades y (No)lugares: procesos de configuración y transformación social del espacio", Medellín: La Carreta editores e Instituto de Estudios Regionales. Universidad de Antioquia.

CERNUDA, L. (2002), “Antología poética”, Madrid: Espasa Calpe.

DELACROIX, E. (2011), "El puente de la visión. Antología de los Diarios”, Madrid: Editorial Tecnos.

GUERRERO, O. (2013), Ingenioso, Don Quijote de La Mancha como aliciente en el itinerario turístico de tres ciudades castellano manchegas, Topofilia, Revista de Arquitectura, Urbanismo y Ciencias Sociales, Vol. IV (Número 1), pp. 428-450.

MATZAT, W. (2013), “La modernidad de Cervantes. Nuevos enfoques teóricos sobre su obra", Madrid: Iberoamericana/ Vervuet.

MÉNDEZ, E. (2010), Topografía de la ciudad turística: un itinerario, Diálogos Latinoamericanos, 17, pp. 5-22.

MÉNDEZ, E. (2012), Imaginario de ciudad turística: una propuesta de abordaje, Topofilia, Vol. III, Número 1, pp. 1-55.

MONTANER, J. M. (2004), Traumas urbanos: la pérdida de la memoria, conferencia pronunciada en el marco del debate "Traumas urbanos. La ciudad y los desastres", en el Centro de Cultura Contemporánea de Barcelona (CCCB). Recuperado 3 de enero de 2012 de http://www.publicspace.org/ ca/text-biblioteca/spa/

NOGUÉ, J. (2008), Territorios sin discurso, paisajes sin imaginarios. Retos y dilemas, Ería, (73-74), pp. 373-382.

PILLET, F. \& PLAZA, J. (Coords.) (2006), "El espacio geográfico del Quijote en Castilla - La Mancha”, Cuenca: Ediciones de la Universidad de Castilla - La Mancha.

PILLET, F. \& PLAZA, J. (2011), El turismo de interior y el patrimonio territorial en Castilla - La Mancha, Cuadernos de Turismo, N 27 , pp. 725-741.

PILLET, F. \& PLAZA, J. (2012). El turismo de interior en la España peninsular: el patrimonio territorial como destino turístico, Boletín de la Asociación Geógrafos Españoles, № 59, pp. 345-366.

PINSON, G. (2011), "Urbanismo y gobernanza de las ciudades europeas: gobernar la ciudad por proyecto", Valencia: P. U. V. 
RODRÍGUEZ, l.; RODRÍGUEZ, A.; RODRÍGUEZ, G. \& CABRERIZO, C. (dirs.) (2015), "Entre pliegues del turismo. Desde el territorio y las representaciones en España y México", Madrid: UAM Ediciones.

RODRíGUEZ, I. (2013), Desafío y dilema en la política pública del "pueblo mágico" mexicano, Revista Topofilia.

RODRígueZ, G. (2010), Roses. Paisajes pintados, paisajes contados, Madrid: Diploma Estudios Avanzados, inédito. Universidad Autónoma de Madrid.

RODRÍGUEZ, G. (2015), Los centenarios: eventos dinamizadores de la cultura, el arte y a la industria del turismo en Castilla - La Mancha. En Rodríguez \& et al. (2015), "Entre Pliegues del turismo. Desde el territorio y las representaciones en España y México" (pp. 69-79), Madrid: UAM Ediciones.

SALVADOR, J. M. (2009), La ciudad y su (re)creación poética en la pintura de Giotto, Actas Icono, 14, N A3, pp. 275-294.

TRÍAS, E. (1991), “La lógica del límite”, Barcelona: Ediciones Destino S. A.

TRÍAS, E. (1997) "El artista y la ciudad”, Barcelona: Anagrama.

\section{NOTAS}

1 Siguiendo al filósofo catalán Eugenio Trías (1991 y 1997).

2 http://entrepliegues.blogspot.com.es/ Los Seminarios Internacionales EntrePliegues, tienen el elemento común de reunir a académicos e investigadores de distintas disciplinas y lugares, vincularlos a la temática común de la ciudad y los modos de gestionarla, vivirla y estudiarla. La ciudad ha sido elemento permanente, también en el reciente Seminario Internacional EntrePliegues3. Itinerarios, lenguajes y ciudades (abril de 2015) pues en ella el turismo actúa produciendo la versión más global del ancestral intercambio de gentes, culturas y productos. Sus efectos se han acelerado al extenderse, a la par que los modos y medios técnicos, económicos y conceptuales de una movilidad creciente, penetrando en cada lugar del planeta como entretela que cose los imaginarios y paisajes contemporáneos rehaciendo los entre pliegues de cada uno de los pueblos y ciudades, reconfigurándolos.

Las ciudades de Nogales (Sonora, México) y las de Almagro (Ciudad Real, Castilla - La Mancha, España), han sido las incorporadas por ahora, bien para las temáticas y procedencias de los artistas y sus exposiciones, bien para la celebración de otros actos como, en el EntrePliegues1 el visionado del Documental sobre el Taller Yonke de Tito Varela -joven cineasta de Nogales-, y en el EntrePliegues2, la visita al Ateneo de Almagro y la exposición de Granalí Rodríguez Chumillas "En la Ruta..." en el Centro Cultural La Corrala. Blog Masters: Ayar Rodríguez y Oscar Guerrero.

3 Resultado del Seminario Internacional EntrePliegues2 es el libro en prensa: Rodríguez, I.; Rodríguez, A.; Rodríguez, G. \& Cabrerizo, C. (dirs.) (2015), “Entre pliegues del turismo. Desde el territorio y las representaciones en España y México", Madrid: UAM Ediciones.

4 Dimensión filosófica del cerco del aparecer, según Trías se entiende como el acontecer del yo dentro del cerco fronterizo que preserva la dimensión secreta y sagrada del ser, o lo que acontece sobre la tierra en la consciencia de la existencia.

5 Siguiendo al filósofo catalán Eugenio Trías (1991).
6 Besse (2010) en “En los pliegues del mundo", también recurre a expresiones geomorfológicas.

7 El cerco del aparecer en el acontecer del devenir (Trías, 1991).

8 Con el puente de la visión de Delacroix, un puente misterioso que se establece entre las almas, entre lo que se ve -la naturaleza exterior-que sin embargo se piensa interiormente, el verdadero pensamiento que es común a todos los hombres (...) y que desaparece al accederse al sentido (Delacroix, 2011:3), dijo de un modo simple y entendible que es el imaginario social y como llega al entendimiento general de lo visible.

9 Además de dar cuenta de otros autores que han tratado esta misma idea: el borrado intencionado de la memoria (Mike Davis, en "Ciudad de cuarzo. Arqueología del futuro en Los Ángeles", 1990; Norman M. Klein, en "The History of Forgetting. Los Angeles and the Erasure of Memory", 1997 y M. Christine Boyer, en “The City of Collective Memory”, 1994) (Montaner, 2004).

10 En el ámbito urbano, el abordaje del estudio de la ciudad y sus paisajes no es nuevo. La imagen urbana se ha trabajado a través de la morfología del paisaje, como elemento clave de la formación de identidades urbanas, desde disciplinas como la Geografía Regional o la Sociología (donde la propiedad del suelo, el plano, los perfiles o las tipologías edificatorias son elementos definitorios y constituyentes de los paisajes de la ciudad). Otras disciplinas como la arquitectura, la fotografía, la literatura o las artes plásticas, también lo han hecho y desarrollado un corpus heterogéneo y poco compartido. También en Geografía la morfología y la imagen de la ciudad se han ido aportando conceptos mutuamente, pero mediante análisis separados y desprestigiándose mutuamente, evidenciando cómo la vanidad de las disciplinas y los investigadores traspasa y contamina al conocimiento que se desvirtúa inservible para acometer los retos de cada tiempo. Es una pugna por el monopolio de los objetos y definiciones de estudio que se acrecienta si además del paisaje como concepto básico introducimos como hacemos a la imagen y al imaginario. El vaivén del pensamiento sigue en las órbitas del control del conocimiento disciplinar. El concepto de paisaje y su aplicación en las políticas de planificación urbana, buscando la síntesis entre el análisis de la forma como elemento objetivable e historiado y el paisaje como contexto visual de la experiencia a través del lenguaje visual y el concepto de imagen como relación ente imagen y medio.

11 Sin referencias a Margarita De Santo analizando a Jean-Paul Sartre sobre el arte y el imaginario.

12 Pese a que el turismo alcance un gran desarrollo desde mediados del siglo XX con múltiples nuevos desarrollos residenciales y terciarios en el propio frente de mar, especializándose en el turismo masivo de sol y playa, el envite de los asentamientos históricos a la movilidad turística creciente, le precede en varias décadas a una enorme mayoría.

13 Otro asunto, es si pone todo su futuro o no, en la apuesta turística, pero no es este un asunto principal ahora, no buscamos saber si el turismo es o no el motor económico, sólo queremos saber si se está catapultando el lugar vendiendo una imagen de si misma que simplifica y anula su razón de ser y que a la larga, podríamos decir va a arruinar al lugar. Una especie de auditoría a futuro. Podríamos decir que atender estos asuntos es muy importante para mantener los dispositivos de alarma encendidos sobre los imaginarios que carga un lugar. 
14 Remitiendo a su estudio El espacio geográfico del Quijote en Castilla - La Mancha.

15 También crea el Instituto de Promoción Turística de Castilla - La Mancha que presentaba a la región en 2009 como materia prima para la imaginación que según Félix Pillet supone la apuesta por distintas rutas literarias basadas en otros autores clásicos vinculados con la región, donde se inserta Cervantes y su obra.

16 Ciudad Real es la provincia más afectada, con el $64 \%$ del total de municipios, seguida de lejos de Albacete, Toledo, Cuenca y Guadalajara, trascurriendo por 2.500 kilómetros a lo largo del $16 \%$ de los municipios de la región central del país, Castilla - La Mancha. Pillet (2012).

17 Trabajos de campo en colaboración y exposición de pintura "En la Ruta..." de Granalí Rodríguez.

18 Por eso en la penúltima edición de EntrePliegues2 hemos abordado "el turismo y el imaginario". Uno de los objetivos principales de esta convocatoria era seguir ofreciendo la posibilidad de reunir un amplio espectro de miradas sobre la transformación que experimentan los lugares en su adaptación a nuevas gentes, costumbres, usos y prácticas por influencia de la valorización y adecuación turística. También, se consiguió la presencia de los miembros de equipos de investigación mexicanos que trabajan los Pueblos Mágicos para valorar la experiencia comparativa de los impactos en España. La sesión académica en el Centro Cultural La Corrala fue densa y fructífera y la sesión práctica de Trabajos de Campo en la provincia de Toledo, recorriendo el tramo 8 del itinerario 1 de la Ruta del Quijote castellano - manchega creada con motivo del Centenario del Quijote en 2005. El balance ha sido excelente y se ha emprendido la publicación de las mismas -ya en prensa-y la actualización del Blog del Seminario Internacional EntrePliegues.

19 Observaciones sobre la evaluación de la Ruta del Quijote entre 2013 y 2014. Parcialmente los contenidos han sido publicados en Rodríguez (2015:69-79).

20 Ver nota anterior.

21 Alumnos de la asignatura Planificación y gestión de turismo interior, cursos 2012 a 2013. Facultad de Ciencias Económicas y Empresariales de la Universidad Autónoma de Madrid.

22 Para lo que se celebró en Seminario Internacional EntrePliegues2 y cuyas aportaciones están en proceso de publicación.

23 Producto artesanal del textil arraigado en Almagro dentro del tramo 8 de la Ruta del Quijote.

24 Cursiva de la autora para enfatizar el carácter de lugares comunes dentro de esta región.

25 Así, el lector imagina España y, según el autor (Matzat 2013) es en las ventas donde todas las clases sociales participan de la vida que en ella se da, sustituyendo la propia casa y alterando la valoración de la vida cotidiana que, va a ser marcada por los quehaceres de Don Quijote. 